\title{
Satisfaction of patients after advanced mono-refractive surgery
}

\author{
Satisfação de pacientes após \\ cirurgia refrativa de monovisão avançada
}

Ignatz Rohrbacher ${ }^{1}$, Luciano Halal Haddad²

\begin{abstract}
Objective: Monovision is a concept that describes the purposely unequal correction of vision from one eye to the other and eye to eye, and is mainly used to correct presbyopia. The main objective was to evaluate patients' satisfaction with advanced monovision refractive surgery. The secondary objectives were to evaluate the need for glasses after surgery, and to analyze the profile of the participants. Methods: A cross-sectional observational study of a series of cases was carried out based on the review of medical records of participants submitted to refractive surgery of monovision in a private ophthalmologic clinic. The population studied was of the non-probabilistic type with $n$ of 50 participants. Sampling was for convenience, and the medical records of the last 50 participants who returned for revision consultation after refractive surgery performed until November 2016 were selected. Results: Fifty patients were analyzed. When questioned about satisfaction with the procedure, the mean score assigned was $9.4 \pm 0.6$ on a scale of 0 to 10 . Regarding the need for glasses after the procedure, $92 \%$ of the patients reported not needing it. Conclusion: We concluded that the satisfaction index with monovision surgery in the sample studied was high and most of the participants reported that they did not require glasses after the procedure. The sample consisted mainly of women with mean age of 52 years, hypermetropes, who underwent surgery in both eyes. Our sample was different from other studies due to the fact that we included most participants with hypermetropes.
\end{abstract}

Keywords: Corneal surgery, Laser; Cornea/surgery; Ophthalmologic surgical procedures; Presbyopia

\section{RESUMO}

Objetivo: Monovisão é um conceito que descreve a correção propositadamente desigual da visão de em um olho para longe e outro olho para perto, sendo utilizada principalmente para correção da presbiopia. O objetivo principal foi avaliar a satisfação dos pacientes com a cirurgia refrativa de monovisão avançada. Os objetivos secundários foram avaliar a necessidade de uso de óculos após a cirurgia, e analise do perfil dos participantes. Métodos: Foi realizado um estudo transversal observacional de série de casos baseado na revisão de prontuários de participantes submetidos a cirurgia refrativa de monovisão em uma clínica oftalmológica privada. A população estudada foi do tipo não-probabilistica com n de 50 participantes. A amostragem foi por conveniência, sendo selecionados os prontuários dos últimos 50 participantes que retornaram para consulta de revisão após a cirurgia refrativa realizada até novembro de 2016. Resultados: Foram analisados 50 prontuários. Quando questionados sobre a satisfação com o procedimento, a nota média atribuída foi 9,4 $\pm 0,6$ dentro de uma escala de 0 a 10 . Sobre a necessidade do uso de óculos após o procedimento, $92 \%$ dos pacientes referiram não necessitar. Os demais $8 \%$ que referiram utilizar eventualmente óculos para perto eram hipermetropes antes da cirurgia Conclusão: Concluímos que o índice de satisfação com a cirurgia de monovisão na amostra estudada foi alto e a maioria dos participantes referiu não necessitar de óculos após o procedimento. A amostra foi composta majoritariamente por mulheres com média de idade de 52 anos, hipermetropes, que realizaram a cirurgia em ambos os olhos. Nossa amostra foi distinta de outros estudos devido ao fato de incluirmos maior parte de participantes hipermetropes.

Descritores: Cirurgia da córnea a Laser; Córnea/cirurgia; Procedimentos cirúrgicos oftalmológicos; Presbiopia

\footnotetext{
${ }^{1}$ Ophthalmology Service, Hospital Governador Celso Ramos, Florianópolis, SC, Brazil.

${ }^{2}$ Centro Especializado da Visão, São Bento do Sul, SC, Brazil.
}

The authors declare no conflicts of interests.

Received for publication 11/04/2017 - Accepted for publication 03/07/2017. 


\section{INTRODUCTION}

$\mathbf{I}$ n Ophthalmology, monovision is a concept describing the purposely unequal correction of vision, in one eye to far sight and the other to near sight, and is being mainly used to correct presbyopia. ${ }^{(1)}$ Presbyopia is a physiological event that comes with aging, starting around 40 years and compromising near sight. The simplest correction for presbyopia is the use of glasses with monofocal or multifocal lenses, but there are other treatments available to substitute or reduce the use of glasses.(2)

The monovision strategy was initially used with contact lenses for the correction of presbyopia and refractive errors. ${ }^{(3)}$ The technological development brought new options to the surgical area, such as the use of monofocal and multifocal posterior chamber intraocular lenses, accommodating posterior chamber intraocular lenses, anterior chamber lenses, surgical procedures using laser to modify the corneal refractive power, and recent techniques of cross-linking collagen and corneal implants. ${ }^{(2,4,5)}$

Laser use in corneal refractive surgery is currently done with the use of excimer laser and femtosecond laser, which are mainly used in PRK and LASIK procedures. In the PRK (photorefractive keratectomy) the excimer is used to change the external curvature of the cornea without the flap making, and thus resulting in the refractive change planned. ${ }^{(2)}$ LASIK (laser in situ keratomileusis) is a technique that causes changes directly to the corneal stroma through the corneal opening, a flap. These changes are planned preoperatively depending on the mode chosen, such as presbiLASIK, mini-monovision, simple or advanced monovision. ${ }^{(2)}$ Advanced monovision represents a greater personalization of the technique. The conventional LASIK technique makes the flap with a microkeratome and uses the excimer laser in the corneal stroma, but more modern techniques use the femtosecond laser to perform the entire procedure. ${ }^{(6)}$ LASIK is the most performed refractive surgery for the correction of myopia, hyperopia and astigmatism, and the use of femtosecond laser in refractive surgery has brought greater accuracy, safety and predictability of the procedure. ${ }^{(6-8)}$ Unlike the use of a blade in the microkeratome, the femtosecond laser makes the flap by means of photodisruption, which forms cavitation bubbles composed of carbon dioxide and water in the planned cleavage plan. ${ }^{(9)}$ The devices available on the market are considered safe, and they can be used in a predictable way to make the flap. ${ }^{(6,10)}$

The satisfaction index with monovision is high when the indications for the procedure are respected. ${ }^{(1)}$

\section{MethodS}

This is an observational cross-sectional study of a series of cases. The main objective was to evaluate the satisfaction of patients with refractive surgery of advanced monovision. The secondary objectives were to evaluate the need for glasses after surgery, and to analyze the profile of patients including age, sex and ametropia. The data was collected by reviewing records of the participants submitted to monovision refractive surgery at a private ophthalmologic clinic in the city of São Bento do Sul - Santa Catarina.
The population studied was non-probabilistic, with $\mathrm{n}$ of 50 participants. Sampling was by convenience, and the medical records selected were of the last 50 participants who returned for revision appointment after refractive surgery performed until November 2016. The medical records of patients who underwent advanced monovision refractive surgery at that clinic were included in the study. The medical records filled out incompletely were excluded. The benefits generated by the study are indirect and late due to the scientific production itself. The risks to the participants were considered minimal due to the analysis of the medical records showing confidential information of the doctor-patient relationship, and the researcher's commitment to the confidentiality of information and anonymity of the participants.

The study was divided into three stages. The first stage comprised the study of the subject, development of the research project, and submission for analysis of the Research Ethics Committee with Human Beings of Universidade do Estado de Santa Catarina (UDESC). The second stage was data collection from the medical records of participants undergoing advanced monovision refractive surgery. The third stage was the tabulation and analysis of the data obtained.

The refractive surgeries were performed by a single surgeon using Star S4 IR ${ }^{\circledast}$ Excimer Laser (Abbott Medical Optics) andFEMTO LDV Z6 ${ }^{\circledast}$ (Ziemer Ophthalmic Systems), after topographic analysis with Galilei ${ }^{\oplus}$ (Ziemer Ophthalmic Systems) and wave front iDesign ${ }^{\circledR}$ or WaveScan ${ }^{\circledR}$ Abbott (Abbott Medical Optics), using calculations for advanced monovision. All procedures were carried out at the same clinic.

The data was tabulated in the program IOS Numbers 3.6.1 ${ }^{\circledR}$. For a description of the results obtained in the study, frequencies and percentages were considered. In compliance with the provisions of the Declaration of Helsinki and Resolution 466/12 of the Brazilian National Health Council, all patients received and signed a free and informed consent form prior to the surgical procedure authorizing the use their medical record data for analysis and publication. This study and its researchers have no conflicts of interest.

\section{Results}

Data from 50 medical records of patients who underwent advanced monovision refractive surgery between April 2014 and November 2016 were analyzed. When asked about satisfaction with the procedure, the average score was $9.4 \pm$ 0.6 on a scale from 0 to 10 and mode 9 (Figure 1). The surgery was performed in both eyes of 43 patients, whereas 7 received surgical indication for only 1 eye. Regarding the need to wear glasses after the procedure, $92 \%$ of patients reported not needing it. The remaining $8 \%$ who reported wearing glasses for near sight were hypermetropic before surgery. The profile of the participants showed that $70 \%$ were female and $30 \%$ male. The average age was $52 \pm 5$ years. Among the ametropias, $66 \%$ were predominantly hypermetropic, $4 \%$ predominantly myopic, $12 \%$ predominantly astigmatitis, $6 \%$ emmetropic, $10 \%$ myopic with astigmatic component, $2 \%$ hypermetropic with astigmatic component, and all presented presbyopia (Figure 2). 


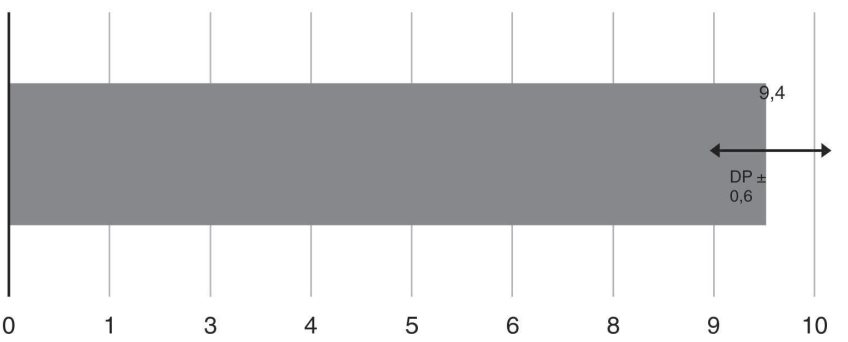

Figure 1. Note attributed by the participant questioned about the satisfaction with the advanced mono-refractive surgery procedure. Mean score of 9.4 in 10 with standard deviation of $\pm 0.6 . \mathrm{N}=50$.

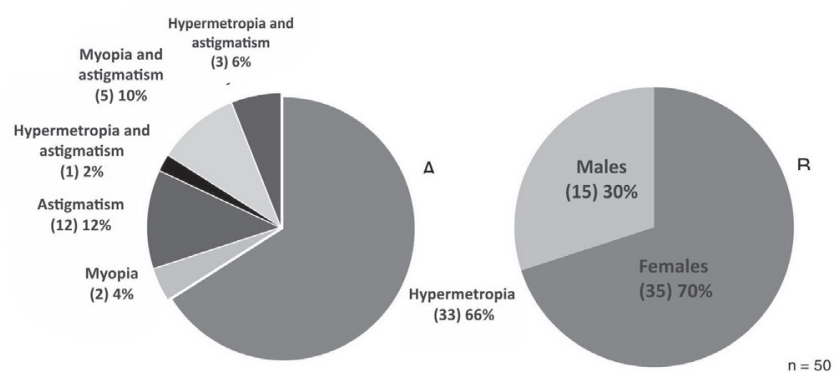

Figure 2. Prevalence of ametropias of participants. B - Prevalence of gender of participants

\section{Discussion}

In this study, we observed that satisfaction with the advanced monovision procedure was high among the participants. Previous studies involving satisfaction with monovision have found high satisfaction indexes, but differ from this one because they have samples composed mainly of myopics. ${ }^{(11,12)}$

The majority of patients reported not needing to wear glasses in the postoperative period, only previously hypermetropic patients who reported eventually needing glasses for near sight. This result is similar to a series of cases performed by Goldberg, who found a greater need for glasses for near sight of eventual use, especially in hypermetropic patients. ${ }^{(12)}$ This indicates that the calculation used for monovision was adequate and met the patients' needs. No data was collected on the reasons for dissatisfaction, which could be investigated in future studies.

The profile of the participants was composed mainly of hypermetropic women with average age of 52 years. It's a similar profile to other studies of satisfaction with monovision: predominantly women over 40 years ${ }^{(1)}$. Among the patients, 7 performed the surgery in only one eye. The possibility of performing the surgery in only one eye is a possible alternative, and it makes the procedure more economical than the bilateral procedure, provided there is indication. ${ }^{(11)}$

We emphasize that the factors to influence positively satisfaction with monovision are the correct indication and desire of the person to have the procedure. It is important to consider the patient's occupation, hobbies, sports, and the need to maintain near sight without correction. ${ }^{(1)}$ The final objective of monovision surgery is the patient satisfaction, and the evaluation by the surgeon of their needs and expectations is an important factor. Factors that lead to greater satisfaction of patients with monovision are the motivation to have the surgery, presbyopia, and the female gender. ${ }^{(13)}$ One bias present was the fact that data was collected by the ophthalmologist during the appointment.

\section{CONCLUSION}

We concluded that the satisfaction index with the monovision surgery in the sample studied was high. Most participants said they did not need glasses after the procedure. Few reported eventually wearing glasses for near sight. They were hypermetropic before surgery. The sample comprised mostly women with an average age of 52 years, hypermetropic, who underwent surgery in both eyes. Our sample was different from other studies due to the fact that most participants included were hypermetropic.

\section{REFERENCES}

1. Goldberg DB. Laser in situ keratomileusis monovision. J Cataract Refract Surg. 2001 ;27(9):1449-55.

2. Paley GL, Chuck RS, Tsai LM. Corneal-based surgical presbyopic therapies and their application in pseudophakic patients. J Ophthalmol. 2016;2016:5263870.

3. Fonda G. Presbyopia corrected with single vision corneal lenses. In: Girard LJ, ed, Corneal and Scleral Contact Lenses; Proceedings of the International Congress. St Louis, MO, CV Mosby;1967. p. 276-9.

4. Kanellopoulos AJ,Asimellis G. Hyperopic correction: clinical validation with epithelium-on and epithelium-off protocols, using variable fluence and topographically customized collagen corneal crosslinking. Clin Ophthalmol. 2014; 8: 2425-33.

5. Vastardis I, Pajic-Eggspühler B, Müller J, Cvejic Z, Pajic B. Femtosecond laser-assisted in situ keratomileusis multifocal ablation profile using a mini-monovision approach for presbyopic patients with hyperopia. Clin Ophthalmol. 2016;10:1245-56.

6. Huhtala A, Pietilä J, Mäkinen P, Uusitalo H. Femtosecond lasers for laser in situ keratomileusis: a systematic review and meta-analysis. Clin Ophthalmol. 2016;10:393-404.

7. Sugar A, Rapuano CJ, Culbertson WW, Huang D, Varley GA, Agapitos PJ, et al. Laser in situ keratomileusis for myopia and astigmatism: safety and efficacy - a report by the American academy of ophthalmology. Ophthalmology. 2002;109(1):175-87.

8. Callou TP, Garcia R, Mukai A, Giacomin NT, de Souza RG, Bechara SJ. Advances in femtosecond laser technology. Clin Ophthalmol. 2016;19(10):697-703.

9. Kurtz RM, Liu X, Elner VM, Squier JA, Du D, Mourou GA. Photodisruption in the human cornea as a function of laser pulse width. J Refract Surg. 1997;13(7):653-8.

10. Kohnen T, Schwarz L, Remy M, Shajari M. Short-term complications of femtosecond laser-assisted laser in situ keratomileusis cuts: Review of 1210 consecutive cases. J Cataract Refract Surg. 2016;42(12):1797-803. 
11. Jaim S, Ou R, Azar DT. Monovision Outcomes in Presbyopic Individuals after Refractive Surgery. Ophthalmology .2001;108(8):1430-3.

12. Goldberg DB. Comparison of myopes and hyperopes after laser in situ keratomileusis monovision. J Cataract Refract Surg. 2003;29(9):1695-701.

13. Farid M,Steinert RF. Patient selection for monovision laser refractive surgery.Curr Opin Ophthalmol. 2009;20(4):251-4.

Autor Correspondente:

Ignatz Rohrbacher

E-mail: ignatz.rohrbacher@gmail.com

\section{ERRATA}

In the scientific paper "Satisfaction of patients after advanced mono-refractive surgery", with the number of DOI 10.5935 / 0034-7280.20170038, published in Revista Brasileira de Oftalmologia, volume 76, number 4, July / August 2017; p. 190-3, on page 190 the name of one of the authors is written in the wrong way:

Where to read:

Ignatz Rohrbache

Read:

Ignatz Rohrbacher 